\author{
Maša FILIPOVIĆ \\ Srna MANDIČ
}

\title{
Mesto Ljubljana: njegova stanovanja, prebivalstvo in stanovanjske razmere
}

\begin{abstract}
Članek je namenjen pregledu ključih značilnosti MOL glede stanovanjske oskrbe .Na stanovanjsko situacijo $v$ mestu pomembno vplivajo predvsem značilnosti sklada stanovanj in značilnosti gospodinjstev ter njihovo razmerje. Pri značilnostih sklada stanovanj gre predvsem za vprašanje kakovosti stanovanj, cenovne dosegljivosti, ustreznosti željam stanovalcev. Druga pomembna dimenzija je značilnost gospodinjstev. Namreč, trendi $v$ Evropi in v Sloveniji gredo $v$ smeri povečevanja števila gospodinjstev, ki pa postajajo vse manjša. Ustrezna stanovanjska politika naj bi skrbela za to, da je pravo razmerje med gospodinjstvi in stanovanji, tj. da stanovanja ustrezajo potrebam in številu gospodinjstev, zaradi česar je potrebno stanje in trende spremljati z ustreznimi podatki. $\mathrm{Na}$ podlagi podatkov iz Stanovanjske ankete $2005 \mathrm{v}$ članku obravnavamo stanovanjske razmere v MOL $\checkmark$ primerjalni perspektivi (glede na Maribor, Slovenijo in nekatera druga evropska mesta), ter na treh ravneh: sklad stanovanj; prebivalstvo, ter stanovanjske razmere.
\end{abstract}

\section{Uvod}

Mestna politika ima pomembno vlogo pri regulaciji stanovanjskega trga. V tujini so tako na primer urbane politike vedno bolj pomembno dopolnilo stanovanjskih politik na državni ravni. Mestne politike težijo $\mathrm{k}$ uravnoteženemu razvoju mesta in pogosto $\mathrm{k}$ sanaciji, prenovi, reneneraciji in gentrifikaciji degradiranih mestnih območij. O urbanih politikah je tako dostopne veliko literature (npr., Atkinson 2004, Priemus 2004, Cole in Etherington 2005, Andersson in Brama 2004, Kruythoff 2003, Tiesdell in Allmendinger 2001, Kearns in Forrest 2000). Pri tem je vloga mesta na stanovanjskem področju lahko večja ali manjša, odvisno od
The article gives an overview of key aspect of housing in Municipality of Ljubljana. The characteristics of households, of housing and their relation influence the housing situation in the city. Characteristic of housing refer mainly to quality of the dwellings, affordability and correspondence to the wishes of the inhabitants. The second important dimensions are households and their characteristics. In Europe and Slovenia increase in number of household can be observed, which in turn are becoming smaller. The housing policy has a role in establishing a balance between households and housing, i.e. ensuring that housing corresponds to the needs of individual households and to their number. For achieving this, knowledge and appropriate data are of vital importance. In the article we present the results of the Housing survey 2005. We observe housing conditions in a comparative perspective (Ljubljana in comparison to Maribor, Slovenia and selected European cities) and according to three dimensions: housing fund, households and housing conditions.

stanovanjske politike $\mathrm{v}$ posamezni državi (glej Doherty 2004, Bush Geertsma 2004, Mandič 1996).

Po letu 1991 se Mestna občina Ljubljana, kot eno izmed stanovanjsko bolj obremenjenih območij, srečuje s številnimi stanovanjskimi problemi, ki so nastali po spremembah političnega in ekonomskega sistema. Še vedno se sooča tudi s problemi nedokončane denacionalizacije in privatizacije stanovanj, kar otežuje vodenje stanovanjske politike.

Stanovanjski program MOL za leto 2007 ima glavni cilj občanom ob njihovem lastnem prizadevanju omogočiti pridobitev primernega stanovanja, skladno z njihovimi
Sklad stanovanj, MOL

Prebivalstvo Stanovanjske razmere

Housing fund, Municipality of Ljubljana, Population,

Housing conditions 
potrebami in možnostmi. Kot opozarja Jakoš (in drugi, 2004), v Ljubljani samo razmerje med številom gospodinjstev in stanovanj ne kaže na stanovanjski primanjkljaj, saj je stanovanj po podatkih popisa (2002) 112.541, gospodinjstev pa 102.646. Vendar pa se tu ne upošteva kakovosti teh stanovanj in primanjkljaja zaradi nastanka novih gospodinjstev. Poleg tega so počitniška stanovanja upoštevali v stanovanjskem skladu, kar kvari pravo sliko. Celoten stanovanjski primanjkljaj na območju MOL tako Jakoš (in drugi, 2004) v svoji raziskavi ocenjuje na 40.000 stanovanj. Kot je ugotovljeno v Stanovanjskem programu MOL, je velik problem občine Ljubljana splošno pomanjkanje stanovanj ter specifično stanovanj za ranljive skupine (neprofitnih stanovanj in bivalnih enot).

$\mathrm{Na}$ stanovanjsko situacijo v mestu pomembno vplivajo predvsem značilnosti sklada stanovanj in značilnosti gospodinjstev ter njihovo razmerje. Pri značilnostih sklada stanovanj gre predvsem za vprašanje kakovosti stanovanj, cenovne dosegljivosti, ustreznosti željam stanovalcev. Druga pomembna dimenzija je značilnost gospodinjstev. Namreč, trendi v Evropi in v Sloveniji gredo v smeri povečevanja števila gospodinjstev, ki pa postajajo vse manjša. Hkrati gredo danes spremembe $v$ družinah $v$ smeri večje diverzifikacije, nastanka novih družinskih oblik - pogostejše so reorganizirane družine, enostarševske družine pa tudi samska gospodinjstva. Ustrezna stanovanjska politika naj bi skrbela za to, da je pravo razmerje med gospodinjstvi in stanovanji, t. j. da stanovanja ustrezajo potrebam in številu gospodinjstev. Pri tem je relevantno proučevanje obstoječega stanja in tudi trendov v prihodnosti, saj se le s pomočjo slednjih lahko oblikuje dobra stanovanjska politika, ki ustreza potrebam in željam samih prebivalcev. Zato je stanje in trende, ki se nakazujejo, nujno spremljati $z$ ustreznimi podatki.

Članek je namenjen pregledu ključnih značilnosti MOL glede stanovanjske oskrbe, zato

Preglednica 1: Sklad stanovanj v slovenskih naseljih po vrsti stanovanja, tipu stavbe, velikosti stavbe ter obdobju izgradnje

\begin{tabular}{|c|c|c|c|c|c|}
\hline & $\begin{array}{c}\text { Ljubljana } \\
(\mathrm{n}=650) \\
(\%)\end{array}$ & $\begin{array}{c}\text { Maribor } \\
\text { (n = 248) } \\
(\%)\end{array}$ & $\begin{array}{c}\text { Druga } \\
\text { mestna naselja } \\
\begin{array}{c}(\mathrm{n}=1352) \\
(\%)\end{array}\end{array}$ & $\begin{array}{c}\text { Nemestna } \\
\text { naselja } \\
(\mathrm{n}=1785) \\
(\%)\end{array}$ & $\begin{array}{c}\text { Slovenija } \\
\text { skupaj } \\
(\mathrm{n}=4008) \\
(\%)\end{array}$ \\
\hline \multicolumn{6}{|l|}{ Vrsta stanovanjske enote } \\
\hline - družinska hiša & 20,6 & 15,3 & 36,1 & 88,0 & 55,4 \\
\hline - stanovanje & 72,5 & 78,6 & 60,8 & 11,2 & 41,7 \\
\hline - garsonjera & 6,3 & 6,0 & 3,0 & 0,6 & 2,6 \\
\hline - drugo & 0,6 & 0,0 & 0,1 & 0,3 & 0,2 \\
\hline Skupaj & 100,0 & 100,0 & 100,0 & 100,0 & 100,0 \\
\hline Tip stavbe & $(n=651)$ & $(n=249)$ & $(n=1325)$ & $(n=1786)$ & $(n=4011)$ \\
\hline - stolpnica ali blok s 5 ali več nadstropji & 35,8 & 32,5 & 19,1 & 1,5 & 14,8 \\
\hline - blok ali stolpič z do 4 nadstropji & 29,8 & 39,4 & 34,9 & 6,2 & 21,5 \\
\hline - enostanovanjska družinska hiša & 11,1 & 7,6 & 19,2 & 63,4 & 36,8 \\
\hline - 2 do 4 stanovanjska družinska hiša & 11,2 & 7,6 & 17,7 & 25,4 & 19,5 \\
\hline - drugačna večstanovanjska hiša & 11,7 & 11,6 & 8,7 & 3,3 & 7,0 \\
\hline - nestanovanjski objekt & 0,5 & 1,2 & 0,5 & 0,3 & 0,4 \\
\hline Skupaj & 100,0 & 100,0 & 100,0 & 100,0 & 100,0 \\
\hline Stavbe po obdobju izgradnje & $(n=606)$ & $(n=239)$ & $(n=1259)$ & $(n=1677)$ & $(n=3781)$ \\
\hline - do leta 1914 & 8,3 & 10,9 & 8,7 & 16,6 & 12,3 \\
\hline - 1914 do 1949 & 9,9 & 12,1 & 8,3 & 9,7 & 9,4 \\
\hline-1950 do 1969 & 30,7 & 33,1 & 24,7 & 19,0 & 23,6 \\
\hline-1970 do 1990 & 45,9 & 40,6 & 51,8 & 43,5 & 46,5 \\
\hline - 1991 ali kasneje & 5,3 & 3,3 & 6,5 & 11,2 & 8,2 \\
\hline Skupaj & 100,0 & 100,0 & 100,0 & 100,0 & 100,0 \\
\hline
\end{tabular}

Vir: Stanovanjska anketa 2005, Univerza v Ljubljani, IDV FDV, CDB 
obravnavamo stanovanjske razmere na treh ravneh:

- sklad stanovanj (njegove značilnosti, kakovost),

- prebivalstvo (predvsem značilnosti gospodinjstev, prisotnost ranljivih skupin) ter

- stanovanjske razmere, ki govorijo o konkretni porazdeljenosti gospodinjstev po skladu stanovanj.

Podatke za MOL tudi primerjamo s podatki za drugo slovensko največje mesto - Maribor, za ostala mestna in nemestna naselja. Tako želimo ugotoviti, ali (in v čem) je položaj v Ljubljani kakorkoli specifičen. Hkrati pa Ljubljano $v$ nekaterih značilnostih primerjamo tudi z drugimi evropskimi glavnimi mesti in jo tako umeščamo v širši evropski prostor.

\section{Kakovost sklada stanovanj v MOL}

V Ljubljani med vrstami stanovanjskih enot (preglednica 1) daleč pred drugimi vrstami prevladujejo stanovanja; to je manj izrazito kot $\mathrm{v}$ Mariboru, bolj izrazito kot $\mathrm{v}$ drugih mestnih naseljih in seveda daleč bolj izrazito kot v nemestnih naseljih, kjer absolutno prevladujejo družinske hiše.

Po tipu stavbe v Ljubljani prevladujejo stavbe, ki so večje od družinskih hiš; to je nekoliko manj izrazito kot $\mathrm{v}$ Mariboru in bolj izrazito kot $\mathrm{v}$ drugih mestnih naseljih; seveda pa je to povsem obratno kot $\mathrm{v}$ nemestnih naseljih, kjer je izrazita večina vseh stavb družinskih
Po obdobju izgradnje večina stavb povsod sodi v desetletja med 1950 in 1990. Zanimivo je stanje v zadnjih petnajstih letih. Delež, ki ga predstavljajo te novejše gradnje, je največji v nemestnih naseljih, in sicer praktično dvakrat večji kot v mestnih. To kaže, da je novejši prirastek stanovanj največji $\mathrm{v}$ nemestnih naseljih. Teh novejših gradenj je v Ljubljani nekaj manj kot $\mathrm{v}$ drugih mestnih naseljih, razen $v$ Mariboru, kjer jih je še manj kot v Ljubljani.

Poglejmo še velikost stanovanj, prikazana je $\mathrm{v}$ preglednici 2 .

Ljubljana ima $\mathrm{v}$ povprečju stanovanja $\mathrm{Z}$ manjšo površino kot druga naselja ( $\mathrm{z}$ izjemo Maribora). Največji naskok pred Ljubljano imajo seveda nemestna naselja, razlika med njihovo mediansko vrednostjo 80 $\mathrm{m}^{2}$ in ljubljanskimi $58 \mathrm{~m}^{2}$ je kar impresivna. Enaka razmerja so tudi pri številu sob na stanovanje.

Preglednica 3: Popisni podatki o velikosti stanovanj za Slovenijo in Ljubljano

\begin{tabular}{|l|r|r|r|r|}
\hline \multirow{2}{*}{$\begin{array}{c}\text { Stanovanja } \\
\text { glede na velikost } \\
\left(\mathbf{m}^{\mathbf{2}}\right)\end{array}$} & \multicolumn{2}{|c|}{ Slovenija } & \multicolumn{2}{c|}{ Ljubljana } \\
\cline { 2 - 5 } & število & $\%$ & število & $\%$ \\
\hline do 20 & 11272 & 1,4 & 1749 & 1,6 \\
\hline $21-40$ & 104502 & 13,4 & 19252 & 17,1 \\
\hline $41-60$ & 200590 & 25,8 & 32534 & 28,9 \\
\hline $61-80$ & 211819 & 27,2 & 32525 & 28,9 \\
\hline $81-100$ & 135890 & 17,5 & 14129 & 12,6 \\
\hline $101+$ & 113699 & 14,6 & 12352 & 11,0 \\
\hline Skupaj & $\mathbf{7 7 7 7 7 2}$ & & $\mathbf{1 1 2 5 4 1}$ & \\
\hline
\end{tabular}

Vir: SURS (www.stat.si)

Preglednica 2: Sklad stanovanj v slovenskih naseljih po velikosti stanovanja

\begin{tabular}{|c|c|c|c|c|c|}
\hline & $\begin{array}{c}\text { Ljubljana } \\
\text { (n= 649) }\end{array}$ & $\begin{array}{l}\text { Maribor } \\
(n=248)\end{array}$ & $\begin{array}{c}\text { Druga } \\
\text { mestna naselja } \\
(n=1321)\end{array}$ & $\begin{array}{c}\text { Nemestna } \\
\text { naselja } \\
(n=1782)\end{array}$ & $\begin{array}{c}\text { Slovenija } \\
\text { skupaj } \\
(n=4000)\end{array}$ \\
\hline \multicolumn{6}{|c|}{ Velikost $\mathrm{v} \mathrm{m}^{2}$} \\
\hline - povprečje & 62,35 & 58,93 & 72,85 & 92,31 & 78,64 \\
\hline$-S D$ & 31,161 & 26,356 & 38,710 & 43,572 & 41,145 \\
\hline - mediana & 58,00 & 55,00 & 64,00 & 80,00 & 70,00 \\
\hline \multicolumn{6}{|l|}{ Število sob } \\
\hline - povprečje & 2,34 & 2,19 & 2,69 & 3,36 & 2,90 \\
\hline$-S D$ & 1,325 & 1,168 & 1,451 & 1,585 & 1,541 \\
\hline - mediana & 2,00 & 2,00 & 2,00 & 3,00 & 3,00 \\
\hline
\end{tabular}

Vir: Stanovanjska anketa 2005, Univerza v Ljubljani, IDV FDV, CDB 
Tudi popisni podatki v spodnji preglednici kažejo, da je v Ljubljani v primerjavi z vso Slovenijo več manjših stanovanj, zlasti tistih do $60 \mathrm{~m}^{2}$

Pri tem je treba opozoriti, da že sama Slovenija dosega relativno nizko povprečno prostorsko raven stanovanj in to ne le v primerjavi z gospodarsko razvitejšimi državami, ampak tudi $z$ državami podobne gospodarske ravni, kot sta na primer Portugalska in Grčija. Zaostaja tudi za številnimi novimi članicami EU, kot so Estonija, Češka, Slovaška (Mandič in Filipovič, 2005). V tem kon-

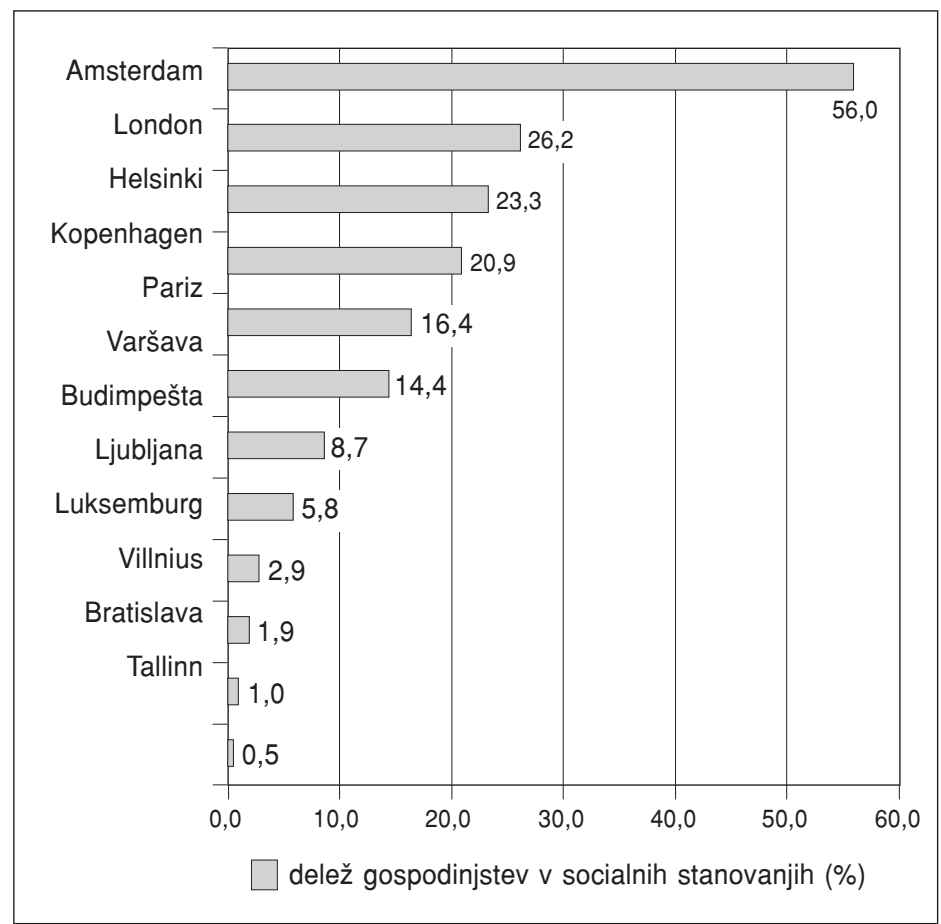

Slika 1: Odstotek gospodinjstev, ki prebiva v socialnem stanovanju $\checkmark$ evropskih glavnih mestih

Vir: Urban Audit 2001 (www.urbanaudit.org) tekstu se torej kaže, da je slovenski zaostanek pri stanovanjskih površinah še bolj izrazit v Ljubljani kot prestolnici.

Pomembna značilnost sklada stanovanj je tudi njegova struktura po tipu oskrbe in lastništvu, kar je podano v preglednici 4 .

V vseh tipih naselij prevladujejo lastniška (t. j. lastniško zasedena) stanovanja (nasproti najemnim), v Ljubljani je to nekaj manj izrazito. Zanimive pa so primerjave po tipih najemnih stanovanj. V Ljubljani je delež najemnih tržnih/službenih stanovanj kar dvakrat višji kot v drugih mestnih naseljih. Presenetljivo pa je delež neprofitnih stanovanj nižji kot v drugih mestnih naseljih, razlika je najbolj občutna v primerjavi z Mariborom.

Podobne rezultate kot Stanovanjska anketa 2005 pokažejo tudi podatki Popisa prebivalstva 2002 (Statistični urad RS). V Ljubljani je torej primerljivo delež neprofitnih stanovanj nižji kot v Sloveniji (Ljubljana - 5,8 \%, Slovenija - 6,5\%), delež najemnikov v profitnem stanovanju pa je višji (Ljubljana - 2,6 \%, Slovenija $-1,6 \%)$.

Zelo nizek delež najemnih stanovanj ter neprofitnih najemnih stanovanj v Ljubljani izstopa tudi $\mathrm{v}$ primerjavi $\mathrm{z}$ drugimi glavnimi mesti v Evropi, kar kaže slika 1.

To kaže, da velika izguba neprofitnih stanovanj, ki je bila posledica privatizacije in denacionalizacije še ni bila niti najmanj nadomeščena in da so $\mathrm{v}$ to smer potrebna še velika vlaganja.

Preglednica 4: Stanovanja po tipu stanovanjske oskrbe lastništvu $\vee$ naseljih $\vee$ RS $\vee \%$

\begin{tabular}{|c|c|c|c|c|c|}
\hline & $\begin{array}{c}\text { Ljubljana } \\
\text { (n = 644) } \\
(\%)\end{array}$ & $\begin{array}{c}\text { Maribor } \\
(n=248) \\
(\%)\end{array}$ & $\begin{array}{c}\text { Druga } \\
\text { mestna naselja } \\
(n=1325) \\
(\%)\end{array}$ & $\begin{array}{c}\text { Nemestna } \\
\text { naselja } \\
(n=1784) \\
(\%)\end{array}$ & $\begin{array}{c}\text { Slovenija } \\
\text { skupaj } \\
(\mathrm{n}=4001) \\
(\%)\end{array}$ \\
\hline Lastnik, solastnik & 78,1 & 80,6 & 80,2 & 88,7 & 83,7 \\
\hline Najemnik neprofitnega stanovanja & 3,9 & 9,3 & 8,5 & 2,1 & 5,0 \\
\hline Najemnik tržnega/službenega stanovanja & 10,7 & 4,4 & 4,5 & 1,6 & 4,2 \\
\hline Uporabnik, ki ne plačuje najemnine & 7,0 & 4,4 & 6,3 & 6,8 & 6,5 \\
\hline Drugo & 0,3 & 1,2 & 0,5 & 0,8 & 0,6 \\
\hline Skupaj & 100,0 & 100,0 & 100,0 & 100,0 & 100,0 \\
\hline
\end{tabular}

Vir: Stanovanjska anketa 2005, Univerza v Ljubljani, IDV FDV, CDB 


\section{Prebivalstvo, demografske značilnosti, prisotnost ranljivih skupin}

Glede velikosti gospodinjstev po podatkih Statističnega urada v Ljubljani šteje povprečno gospodinjstvo 2,6 člana, kar je nekoliko manj od povprečja za Slovenijo (2,8 člana). Po starostni strukturi ljubljansko prebivalstvo ne odstopa izrazito od slovenskega povprečja, kaže le nekoliko večji delež starejšega prebivalstva od 60 let.

Te specifičnosti prebivalstva Ljubljane se kažejo tudi $v$ podatkih Stanovanjske ankete 2005, kjer jih primerjamo še z drugimi naselji v Sloveniji (v preglednici 6).
V Ljubljani je znatno več enočlanskih gospodinjstev kot v Sloveniji in vseh drugih naseljih, tudi parov brez otrok je več kot povsod drugod, razen v Mariboru. Starejših nad 65 let je le malo več kot drugod.

Preglednica 5: Podatki o prebivalstvu po starosti za Slovenijo in Ljubljano

\begin{tabular}{|l|c|c|c|c|}
\hline \multirow{2}{*}{$\begin{array}{c}\text { Prebivalstvo } \\
\text { glede } \\
\text { na starost }\end{array}$} & \multicolumn{2}{|c|}{ Slovenija } & \multicolumn{2}{c|}{ Ljubljana } \\
\cline { 2 - 5 } & $\mathbf{n}$ & $\%$ & $\mathbf{n}$ & $\%$ \\
\hline do 19 let & 430196 & 21,9 & 52255 & 19,7 \\
\hline $20-39$ & 586794 & 29,9 & 78967 & 29,7 \\
\hline $40-59$ & 554456 & 28,2 & 78515 & 29,5 \\
\hline $60-79$ & 342020 & 17,4 & 48058 & 18,1 \\
\hline 80 in več & 50570 & 2,6 & 8086 & 3,0 \\
\hline Skupaj & $\mathbf{1 9 6 4 0 3 6}$ & & 265881 & \\
\hline
\end{tabular}

Vir: SURS (www.stat.si)

Preglednica 6: Sestava anketirancev po tipu gospodinjstva in po starosti po naseljih v RS

\begin{tabular}{|c|c|c|c|c|c|}
\hline & $\begin{array}{c}\text { Ljubljana } \\
\text { (n = 647) } \\
(\%)\end{array}$ & $\begin{array}{c}\text { Maribor } \\
(\mathrm{n}=248) \\
(\%)\end{array}$ & $\begin{array}{c}\text { Druga } \\
\text { mestna naselja } \\
n=1320) \\
(\%)\end{array}$ & $\begin{array}{c}\text { Nemestna } \\
\text { naselja } \\
(n=1781) \\
(\%)\end{array}$ & $\begin{array}{c}\begin{array}{c}\text { Slovenija } \\
\text { skupaj } \\
(n=3996) \\
(\%)\end{array}\end{array}$ \\
\hline \multicolumn{6}{|l|}{ Tip gospodinjstva } \\
\hline - enočlansko & 31,8 & 20,6 & 19,1 & 14,5 & 19,2 \\
\hline - par brez otrok & 18,7 & 21,8 & 15,3 & 16,2 & 16,7 \\
\hline - par z otroki & 28,3 & 34,3 & 41,7 & 40,1 & 38,3 \\
\hline - enostarševska družina & 7,0 & 8,5 & 9,0 & 5,6 & 7,1 \\
\hline - ostali & 14,2 & 14,9 & 14,9 & 23,5 & 18,6 \\
\hline Skupaj & 100,0 & 100,0 & 100,0 & 100,0 & 100,0 \\
\hline Starost & $(n=642)$ & $(n=248)$ & $(n=1317)$ & $(n=1774)$ & $(\mathrm{n}=3981)$ \\
\hline-15 do 24 let & 7,5 & 4,8 & 5,0 & 3,3 & 4,6 \\
\hline-25 do 34 let & 17,8 & 11,7 & 11,6 & 12,1 & 12,8 \\
\hline-35 do 44 let & 17,9 & 19,0 & 21,6 & 21,0 & 20,6 \\
\hline-45 do 54 let & 19,6 & 30,6 & 26,3 & 24,5 & 24,7 \\
\hline-55 do 64 let & 17,9 & 14,5 & 17,5 & 19,9 & 18,4 \\
\hline-65 let in več & 19,3 & 19,4 & 18,0 & 19,3 & 18,9 \\
\hline Skupaj & 100,0 & 100,0 & 100,0 & 100,0 & 100,0 \\
\hline
\end{tabular}

Vir: Stanovanjska anketa 2005, Univerza v Ljubljani, IDV FDV, CDB

Preglednica 7: Prisotnost izbranih ranljivih skupin (\% gospodinjstev) v naseljih RS

\begin{tabular}{|c|c|c|c|c|c|}
\hline & $\begin{array}{c}\text { Ljubljana } \\
\text { (n = 650) } \\
(\%)\end{array}$ & $\begin{array}{c}\text { Maribor } \\
(n=248) \\
(\%)\end{array}$ & $\begin{array}{c}\text { Druga } \\
\text { mestna naselja } \\
\mathrm{n}=1352) \\
(\%)\end{array}$ & $\begin{array}{c}\text { Nemestna } \\
\text { naselja } \\
(n=1785) \\
(\%)\end{array}$ & $\begin{array}{c}\text { Slovenija } \\
\text { skupaj } \\
(n=4008) \\
(\%)\end{array}$ \\
\hline Enostarševska gospodinjstva & 7,0 & 8,5 & 9,0 & 5,6 & 7,1 \\
\hline Družina $\mathrm{z}$ otroki do 18 let & 22,6 & 24,6 & 34,0 & 35,6 & 32,3 \\
\hline Stari 65 in več let & 19,3 & 19,4 & 18,0 & 19,3 & 18,9 \\
\hline Revni * & 18,8 & 30,5 & 29,9 & 44,4 & 34,7 \\
\hline
\end{tabular}

* Revni so bili definirani kot tista gospodinjstva, ki imajo manj kot 60 mediane ekvivalentnega dohodka.

Vir: Stanovanjska anketa 2005, Univerza v Ljubljani, IDV FDV, CDB 
Preglednica 8: Primerjava Ljubljane in drugih evropskih glavnih mest glede na značilnosti gospodinjstva

\begin{tabular}{|l|c|c|}
\hline \multicolumn{1}{|c|}{ Mesto } & $\begin{array}{c}\text { Enostarševska } \\
\text { gospodinjstva (\%) }\end{array}$ & $\begin{array}{c}\text { Samska upokojenska } \\
\text { gospodinjstva (\%) }\end{array}$ \\
\hline Riga & 24,27 & 14,03 \\
\hline Tallinn & 6,61 & 13,63 \\
\hline Bratislava & 8,74 & 14,32 \\
\hline Budimpešta & 13,13 & 15,46 \\
\hline Praga & 16,46 & 11,85 \\
\hline Varšava & 5,14 & 10,99 \\
\hline Ljubljana & $\mathbf{1 2 , 7 2}$ & $\mathbf{1 5 , 1 3}$ \\
\hline Dunaj & 10,61 & - \\
\hline Berlin & 7,71 & 12,47 \\
\hline Kopenhagen & 4,64 & 15,06 \\
\hline Amsterdam & 6,85 & 10,15 \\
\hline Helsinki & 7,73 & 12,27 \\
\hline Pariz & 4,07 & 13,08 \\
\hline London & 7,60 & 12,67 \\
\hline Luksemburg & 3,99 & 10,68 \\
\hline Villnius & 5,04 & 10,62 \\
\hline
\end{tabular}

Vir: Urban Audit, 2001 (www.urbanaudit.org)

Preglednica 9: Demografski kazalci (na 1000 prebivalcev)

\begin{tabular}{|l|c|c|c|}
\hline & Ljubljana & Maribor & Slovenija \\
\hline Živorojeni & 8,2 & 7,7 & 8,7 \\
\hline Umrli & 9,1 & 10,6 & 9,7 \\
\hline Naravni prirast & $-0,9$ & $-2,9$ & $-1,1$ \\
\hline Selitveni prirast s tujino & 2,6 & 1,2 & 1,7 \\
\hline Selitveni prirast med občinami & $-5,3$ & $-5,1$ & 0,0 \\
\hline Skupni prirast & $-3,6$ & $-6,8$ & 0,6 \\
\hline
\end{tabular}

Vir: Prebivalstvo Slovenije 2003, SURS

Preglednica 10: Selitveni prirast v občinah, ki mejijo z ljubljansko občino

\begin{tabular}{|l|c|c|}
\hline \multicolumn{1}{|c|}{ Mesto } & $\begin{array}{c}\text { Selitveni prirast } \\
\text { med občinami }\end{array}$ & Skupni prirast \\
\hline Domžale & 5,5 & 11,0 \\
\hline Grosuplje & 13,8 & 23,7 \\
\hline Litija & 1,3 & 0,1 \\
\hline Trzin & 17,2 & 24,1 \\
\hline Brezovica & 14,9 & 20,9 \\
\hline Medvode & 3,6 & 5,3 \\
\hline Ig & 22,9 & 23,8 \\
\hline Škofljica & 19,0 & 23,9 \\
\hline Šmartno pri Litiji & 6,2 & 5,6 \\
\hline Dol pri Ljubljani & 18,1 & 17,9 \\
\hline Dobrova-Polhov Gradec & 7,4 & 11,6 \\
\hline Vodice & 5,6 & 9,6 \\
\hline Mengeš & 0,4 & 5,5 \\
\hline Ivančna Gorica & 7,5 & 8,1 \\
\hline
\end{tabular}

Vir: Prebivalstvo Slovenije 2003, SURS

Opomba: Podatki so na 1000 prebivalcev
Poglejmo še prisotnost ranljivih skupin v celotnem prebivalstvu, kar prikazuje preglednica 7.

Glede enostarševskih gospodinjstev primerjava $z$ drugimi naselji v Sloveniji pokaže, da je Ljubljana zelo blizu slovenskega povprečja, ima več tovrstnih gospodinjstev kot nemestna naselja, toda manj kot druga mestna naselja. Ima manj družin $\mathrm{Z}$ otroki do 18 let kot druga naselja in malenkost več starejšega prebivalstva kot druga mestna naselja (razen Maribora). Delež revnih je v Ljubljani nižji kot $\mathrm{v}$ vseh ostalih naseljih, skoraj polovico nižji kot v Mariboru.

$\mathrm{V}$ mednarodni primerjalni perspektivi (preglednica 8) se kaže, da sta ljubljanska odstotka enostarševskih gospodinjstev in tudi samskih upokojenskih gospodinjstev med najvišjimi v primerjavi z večino evropskih prestolnic.

Za mesto in njegovo stanovanjsko politiko je izrazitega pomena tudi selitveni trend. Po eni strani je bila Ljubljana kot glavno (in največje) mesto Slovenije v preteklosti predvsem prostor priselitev. V takšnih okoliščinah so že tako ranljive skupine še bolj pritisnjene na obrobje, saj se v rastočih cenah ne morejo spopasti $\mathrm{v}$ neenakem boju za to omejeno dobrino - stanovanje in so primorane imeti premajhna ali drugače neprimerna stanovanja. Po drugi strani imajo težo tudi obratni tokovi - odseljevanje (iz ljubljanske občine, predvsem v okoliške, sosednje občine). Podatki Statističnega urada (glej preglednico 9 in 10) kažejo, da ima ljubljanska občina negativni selitveni saldo. Podobno negativni saldo ima tudi mariborska občina. Hkrati pa lahko opažamo izrazito pozitivni selitveni prirast v občinah okoli Ljubljane, najbolj izrazito v občinah Grosuplje, Trzin, Brezovica, Ig, Škofljica in Dol pri Ljubljani.

\section{Stanovanjske razmere prebivalstva Ljubljane}

Obravnavali smo kakovost sklada stanovanj v Ljubljani ter značilnosti prebivalstva, v tem delu pa ta dva elementa povežemo in analiziramo, kako prebivalstvo stanuje, torej kakšne so njihove stanovanjske razmere. Posebej nas zanima, ali se s tega zornega kota kažejo v Ljubljani kakšne posebnosti v primerjavi z drugimi naselji. 
Najprej poglejmo, kako pogoste so težave v zvezi s stanovanjem, ki jih zaznava prebivalstvo v naseljih. Premalo prostora zaznava več kot tretjina prebivalstva Ljubljane, kar je več kot v drugih naseljih RS (razen v Mariboru). Bolj kot drugod sta zaznani tudi težavi "premalo svetlobe « in "pomanjkljive napeljave«, nekaj manj kot drugod pa je izražena težava $\mathrm{z}$ vlago $\mathrm{v}$ stanovanju.

Tudi pri vseh težavah v zvezi s svobodo in varnostjo uporabe stanovanja je v Ljubljani zaznanih znatno več težav kot v drugih naseljih, kar je nedvomno posledica večje prisotnosti tržnih najemnih stanovanj.

Težave v stanovanjskem okolju so zaznane, kot je bilo pričakovati glede na razlike med urbanim in neurbanim prostorom, vendar ne povsem enotno. Pri dveh tipično urbanih težavah - težave s parkiranjem in onesnažen zrak - so v Ljubljani najbolj izražene, in sicer nekoliko bolj kot $\mathrm{v}$ drugih mestnih naseljih in seveda veliko bolj kot $\mathrm{v}$ nemestnih. Pri dveh drugih tipičnih urbanih težavah - hrup in pomanjkanje varnega prosto- ra za igro otrok - pa je Ljubljana v podobnem položaju kot druga mestna naselja (razen Maribora, kjer so težave izrazitejše). Glede rekreacijskih površin je Ljubljana na boljšem od drugih mestnih naselij, saj tovrstne težave Ljubljančani manj zaznavajo. Če k temu dodamo še urbano prednost prometne povezave, se v tem pogledu Ljubljana pokaže kot naselje $\mathrm{z}$ bolj kakovostnim okoljem.

Poglejmo še nekaj drugih uveljavljenih kazalcev stanovanjskega standarda, podanih $\mathrm{v}$ preglednici 12 .

Po sintetičnem indeksu stanovanjskih razmer, ki združuje več kazalcev, se pokaže, da so v Ljubljani neprimerne stanovanjske razmere nekoliko bolj izražene kot $\mathrm{v}$ drugih naseljih, kar zadeva gostoto naselitve v stanovanjih pa je položaj nekoliko ugodnejši kot v drugih mestnih naseljih. V Ljubljani je namreč nižji odstotek gospodinjstev, ki ne dosegajo sobe na člana gospodinjstva, pa tudi povprečna površina stanovanja na osebo je višja kot v drugih mestnih naseljih, najbolj

Preglednica 11: Pogostost navedenih težav* med gospodinjstvi v naseljih RS

\begin{tabular}{|c|c|c|c|c|c|}
\hline & $\begin{array}{c}\text { Ljubljana } \\
(n=650) \\
(\%)\end{array}$ & $\begin{array}{c}\text { Maribor } \\
(\mathrm{n}=248) \\
(\%)\end{array}$ & $\begin{array}{c}\text { Druga } \\
\text { mestna naselja } \\
n=1352) \\
(\%)\end{array}$ & $\begin{array}{c}\text { Nemestna } \\
\text { naselja } \\
(n=1785) \\
(\%)\end{array}$ & $\begin{array}{c}\text { Slovenija } \\
\text { skupaj } \\
(n=4008) \\
(\%)\end{array}$ \\
\hline \multicolumn{6}{|c|}{ Fizične značilnosti stanovanjske enote } \\
\hline - premalo prostora & 35,2 & 36,3 & 30,9 & 20,8 & 27,5 \\
\hline - vlaga & 11,2 & 13,3 & 11,4 & 22,2 & 16,3 \\
\hline - premalo svetlobe & 15,7 & 9,7 & 13,4 & 11,4 & 12,7 \\
\hline - pomanjkljive napeljave & 26,2 & 19,0 & 26,1 & 22,1 & 23,9 \\
\hline \multicolumn{6}{|l|}{ - varnost, svoboda } \\
\hline - negotovost glede stanovanja & 11,0 & 6,9 & 9,4 & 5,3 & 7,7 \\
\hline - premalo zasebnosti & 14,2 & 10,5 & 10,4 & 6,2 & 9,1 \\
\hline - preveč omejitev & 8,8 & 5,6 & 8,2 & 5,2 & 6,8 \\
\hline \multicolumn{6}{|l|}{ Stanovanjsko okolje } \\
\hline - težave s parkiranjem & 36,3 & 32,8 & 30,5 & 6,4 & 20,8 \\
\hline - slabe prometne povezave & 8,2 & 8,5 & 21,6 & 35,3 & 24,7 \\
\hline - ni rekreacijskih površin & 34,8 & 38,6 & 40,8 & 33,8 & 36,6 \\
\hline - onesnažen zrak & 53,2 & 50,4 & 47,1 & 25,4 & 38,6 \\
\hline- hrup & 42,3 & 45,6 & 42,5 & 22,9 & 33,9 \\
\hline - ni varnega prostora za igro otrok & 38,0 & 39,6 & 39,5 & 15,8 & 28,7 \\
\hline \multicolumn{6}{|l|}{ Zadovoljstvo s stanovanjem } \\
\hline - ni zadovoljen & 10,6 & 14,6 & 8,0 & 7,7 & 8,7 \\
\hline - niti-niti & 26,2 & 22,3 & 24,9 & 26,3 & 25,5 \\
\hline
\end{tabular}

* Subjektivna ocena, da je težava zelo huda, huda ali niti-niti.

Vir: Stanovanjska anketa 2005, Univerza v Ljubljani, IDV FDV, CDB 
opazno v primerjavi z Mariborom. Po številu sob na osebo dovolj opaznih razlik ni. V Ljubljani je tudi odstotek tistih, ki so s stanovanjem nezadovoljni, višji kot v drugih naseljih (razen v Mariboru, ki Ljubljano prekaša tudi $v$ tem).

Opazno je torej, da dosega Ljubljana - kljub pretežno manjšim stanovanjem - boljši površinski standard na osebo, saj so tudi gospodinjstva v povprečju manjša kot drugod.

Seveda pa se dokaj ugodna slika Ljubljane glede prostornosti stanovanj nekoliko relativizira, če jo postavimo v mednarodno primerjavo. Podatki v naslednji preglednici pokažejo, da je relativna površina na osebo v Ljubljani med nižjimi.

Posebno vprašanje seveda zadeva položaj nekaterih družbenih skupin, pri katerih so stanovanjske razmere drugačne kot v celotni populaciji. Tako se ob relativno ugodnih površinskih standardih v Ljubljani vprašanje prenaseljenosti lahko zaostri v nekaterih skupinah. Medtem ko v drugem članku (v tem sklopu) problematiko ranljivih skupin posebej obravnavamo, tukaj poglejmo problem prenaseljenosti, pri čemer je kot prenaseljeno definirano tisto stanovanje, $\mathrm{v}$ katerem na sobo pride več kot 1 oseba. Podatki za Ljubljano so v naslednji preglednici.
Vidimo, da je prenaseljenosti izpostavljenih kar $49 \%$ tričlanskih gospodinjstev in $28 \%$ dvočlanskih gospodinjstev Ljubljane. V Ljubljani se ta problem kaže bolj izrazito kot v Sloveniji nasploh in še neprimerno izraziteje kot v nekaterih drugih državah. Mandič in Filipovič (2005) sta namreč ocenili, da med slovenskimi tričlanskimi gospodinjstvi živi v

Preglednica 13: Povprečna bivalna povpršina v $\mathrm{m}^{2}$ na osebo $v$ Ljubljani in nekaterih drugih evropskih mestih

\begin{tabular}{|l|c|}
\hline \multicolumn{1}{|c|}{ Mesto } & $\begin{array}{c}\text { Povp. bivalna površina } \\
\text { (m² } \text { na osebo) }\end{array}$ \\
\hline Riga & 13,20 \\
\hline Tallinn & 21,75 \\
\hline Bratislava & 18,70 \\
\hline Budimpešta & 33,00 \\
\hline Praga & 18,00 \\
\hline Varšava & 21,60 \\
\hline Ljubljana & 26,20 \\
\hline Berlin & 38,30 \\
\hline Kopenhagen & 44,00 \\
\hline Amsterdam & 34,00 \\
\hline Helsinki & 32,50 \\
\hline Pariz & 34,90 \\
\hline Luksemburg & 40,40 \\
\hline Villnius & 19,10 \\
\hline
\end{tabular}

Vir: Urban Audit, 2001 (www.urbanaudit.org)

Preglednica 12: Gospodinjstva po izbranih splošnih kazalcih stanovanjskih razmer

\begin{tabular}{|c|c|c|c|c|c|}
\hline & $\begin{array}{l}\text { Ljubljana } \\
(\mathrm{n}=650)\end{array}$ & $\begin{array}{l}\text { Maribor } \\
(\mathrm{n}=248)\end{array}$ & $\begin{array}{c}\text { Druga } \\
\text { mestna naselja } \\
n=1352)\end{array}$ & $\begin{array}{c}\text { Nemestna } \\
\text { naselja } \\
(n=1785)\end{array}$ & $\begin{array}{c}\begin{array}{c}\text { Slovenija } \\
\text { skupaj } \\
(n=4008)\end{array}\end{array}$ \\
\hline $\begin{array}{l}\text { Gospodinjstva, ki imajo neprimerne } \\
\text { stanovanjske razmere }\end{array}$ & $34,2 \%$ & $31,1 \%$ & $29,6 \%$ & $23,5 \%$ & $27,8 \%$ \\
\hline $\begin{array}{l}\text { Gospodinjstva z manj kot sobo na člana } \\
\text { gospodinjstva }\end{array}$ & $38,7 \%$ & $46,0 \%$ & $43,2 \%$ & $34,0 \%$ & $38,5 \%$ \\
\hline \multicolumn{6}{|l|}{ Površina v $\mathrm{m}^{2}$ na osebo } \\
\hline - povprečje & 32,1761 & 28,2649 & 30,8074 & 35,7324 & 33,0073 \\
\hline$-S D$ & 18,68755 & 17,82248 & 20,19754 & 24,58207 & 21,98994 \\
\hline - mediana & 27,0000 & 21,6219 & 25,0000 & 28,9390 & 26,6667 \\
\hline \multicolumn{6}{|l|}{ Število sob na osebo } \\
\hline - povprečje & 1,1484 & 1,0200 & 1,1183 & 1,2921 & 1,1945 \\
\hline$-\mathrm{SD}$ & 0,77523 & 0,68287 & 0,77773 & 0,86688 & 0,81788 \\
\hline - mediana & 1,0000 & 1,0000 & 1,0000 & 1,0000 & 1,0000 \\
\hline
\end{tabular}

* Neprimerne stanovanjske razmere so definirane kot: gospodinjstvo biva v stanovanju, ki ima vsaj eno od osnovnih pomanjkljivosti, t. j. ni stranišča na izpiranje, huda ali zelo huda pomanjkljivost inštalacij, huda ali zelo huda vlaga, hudo ali zelo hudo pomanjkanje dnevne svetlobe, ali/in primanjkuje prostor.

Vir: Stanovanjska anketa 2005, Univerza v Ljubljani, IDV FDV, CDB 
Preglednica 14: Problem prenaseljenosti v Ljubljani

\begin{tabular}{|c|c|c|c|c|c|}
\hline \multirow[b]{2}{*}{ Število sob } & \multicolumn{4}{|c|}{ Število članov gospodinjstva } & \multirow{2}{*}{$\begin{array}{c}\text { Skupaj } \\
\text { (n=658) } \\
(\%)\end{array}$} \\
\hline & $\begin{array}{c}1 \\
(n=212) \\
(\%)\end{array}$ & $\begin{array}{c}2 \\
(n=172) \\
(\%)\end{array}$ & $\begin{array}{c}3 \\
n=136) \\
(\%)\end{array}$ & $\begin{array}{c}4 \\
(n=92) \\
(\%)\end{array}$ & \\
\hline Garsonjera & 14,6 & 5,8 & 2,2 & & 6,7 \\
\hline 1 soba & 30,7 & 22,1 & 3,7 & 5,4 & 17,2 \\
\hline 2 sobi & 37,3 & 27,3 & 43,4 & 22,8 & 33,6 \\
\hline 3 sobe & 14,6 & 32,0 & 33,1 & 42,4 & 28,4 \\
\hline 4 sobe & 2,4 & 9,3 & 14,7 & 19,6 & 10,2 \\
\hline 5 sob & 0,5 & 2,3 & 2,2 & 5,4 & 2,6 \\
\hline Skupaj & 100,0 & 100,0 & 100,0 & 100,0 & 100,0 \\
\hline
\end{tabular}

Opomba: V tabeli zaradi majhnega števila niso prikazana gospodinjstva z več kot 4 člani in ne stanovanja z več kot 5 sobami.

Vir: Stanovanjska anketa 2005, Univerza v Ljubljani, IDV FDV, CDB

prenaseljenem stanovanju kar $37 \%$, v Avstriji in Franciji pa manj kot $15 \%$. Podobno je tudi pri dvočlanskih gospodinjstvih. V Sloveniji jih je kar $17 \%$ izpostavljenih prenaseljenosti, v Franciji in Avstriji pa manj kot $5 \%$.

\section{Sklepi}

Splošni pregled značilnosti stanovanj, prebivalstva in stanovanjskih razmer v Ljubljani je v primerjavi z drugimi naselji v Sloveniji pokazal na naslednje značilnosti:

- Sklad stanovanj v Ljubljani vsebuje manj novejših stanovanj kot druga naselja (razen Maribora); stanovanja so v povprečju manjša kot drugod; delež najemnih tržnih/službenih stanovanj pa je kar dvakrat višji kot v drugih mestnih naseljih, medtem ko je delež neprofitnih stanovanj nižji kot $\mathrm{v}$ drugih mestnih naseljih in tudi občutno nižji kot $\mathrm{v}$ Mariboru.

- Gospodinjstva so v Ljubljani v povprečju manjša kot v Sloveniji. Po sestavi gospodinjstev in prisotnosti ranljivih skupin pa se pokaže naslednje. Glede enostarševskih gospodinjstev primerjava $z$ drugimi naselji v Sloveniji pokaže, da je Ljubljana zelo blizu slovenskega povprečja glede odstotka enostarševskih gospodinjstev. Ima jih več kot nemestna naselja, toda manj kot druga mestna naselja. Ima manj družin $\mathrm{Z}$ otroki do 18 let kot druga naselja in malenkost več starejšega prebivalstva kot druga mestna naselja (razen Maribora). Delež revnih je v Ljubljani nižji kot v vseh ostalih naseljih, skoraj polovico nižji kot $\mathrm{v}$ Mariboru. Kaže se tudi, da ima ljubljanska občina negativni selitveni saldo (po- dobno kot mariborska občina). Hkrati obstaja izrazit pozitivni saldo - selitveni prirast v občinah okoli Ljubljane, zlasti Grosuplje, Trzin, Brezovica, Ig, Škofljica in Dol pri Ljubljani.

- Stanovanjske razmere: v Ljubljani pogosteje kot v drugih naseljih (razen Maribora) zaznavajo, da je v stanovanju "premalo prostora«, »premalo svetlobe« in so »pomanjkljive napeljave«, nekaj manj kot drugod pa je izražena težava z vlago v stanovanju. Glede kakovosti stanovanjskega okolja sta v Ljubljani dve tipično urbani težavi - parkiranje in onesnažen zrak izraženi bolj kot drugod, dve drugi - hrup in pomanjkanje varnega prostora za igro otrok - pa podobno kot v drugih mestnih naseljih, a manj izrazito kot v Mariboru. Glede rekreacijskih površin je Ljubljana na boljšem od drugih mestnih naselij, če pa k temu dodamo še urbano prednost prometne povezave, se Ljubljana pokaže kot naselje $\mathrm{z}$ bolj kakovostnim okoljem. Tudi glede relativne stanovanjske površine na osebo se razmere $v$ Ljubljani kažejo kot relativno ugodne v primerjavi z drugimi naselji: nižji je odstotek gospodinjstev, ki ne dosegajo sobe na člana gospodinjstva, pa tudi povprečna površina stanovanja na osebo je višja kot v drugih mestnih naseljih, najbolj opazno $\mathrm{v}$ primerjavi z Mariborom.

- Primerjalno gledano je potrebno opozoriti na dvoje. Prvič, relativno ugodne stanovanjske razmere v Ljubljani se pokažejo kot manj zadovoljive, če jih primerjamo z drugimi evropskimi prestolnicami, kjer so stanovanjske površine praviloma občutno višje. Drugič, odprto ostaja vprašanje, v 
kakšnem položaju so ranljive skupine, saj so pri njih težave praviloma veliko večje kot $\mathrm{v}$ splošni populaciji.

asist. dr. Maša Filipović, Fakulteta za družbene ede, Univerza $v$ Ljubljani

E-pošta: masa.filipovic@fdv.uni-lj.si

doc. dr. Srna Mandič, znanstvena svetnica, Fakulteta za družbene vede, Univerza v Ljubljani

E-pošta: srna.mandic@fdv.uni-lj.si

\section{Viri in literatura}

Andersson, R., Brama, A. (2004). Selective Migration in Swedish Distressed Neighbourhoods: Can Area-based Urban Policies Counteract Segregation processes? Housing studies 19 (4), 517-539.

Atkinson, R. (2004): The evidence opf the impact of gentrification: new lessons for urban rainessance? European Journal of hosuing policy 4(1), 107-131.

Bush-Geertsma, V. (2004) The changing role of the state in German housing and social policy. European Journal of hosuing policy 4(3), 303-321

Cole, I., Etherington, D. (2005): Neighbourhood renewal policy and spatial differntiation in housing markets: recent trends in England and Denmark. European Journal of hosuing policy 5(1), 77-97.

Doherty, J. (2004): European housing policy: Bringing the state back in? European Journal of hosuing policy 4(3), 253-260
Jakoš, A. et al. (2004): Ocena stanovanjskega primanjkljaja. Končno poročilo. Ljubljana: Urbanistični inštitut RS

Kearns, A., Forrest, R. (2000): Social cohesion and multilevel urban governance. Urban Studies, 37, 5-6.

Kruythoff, H. (2003): Dutch Urban restructuring policy in action against sociospatial segregation: sense or nonsense? European Journal of hosuing policy 3(2), 193-215.

Mandič, S. (1996): Stanovanje in država. Ljubljana: Znanstveno in publicistično središče.

Mandič, S., Filipovič, M. (2005): Stanovanjski primanjkljaj v Sloveniji: problem, ki ga ni?. Teor. praksa, jul./dec., letn. 42, št. 4/6, str. 704-718

Popisa prebivalstva 2002. Statistični urad RS. Dostopno na: www.stat.si/popis2002/si

Priemus, H. (2004): Housing and new urban renewal: current policies in the Netherlands. European Journal of hosuing policy 4(2), 229-246.

Stanovanjska anketa 2005. Zaključno poročilo. Nosilka: dr. Srna Mandič. Naročnik: Stanovanjski sklad RS. Ljubljana, februar 2006

Stanovanjski program Mestne občine Ljubljana za leto 2007. Javni stanovanjski sklad Mestne občine Ljubljana. Ljubljana, januar 2007

Tiesdell, S., Allmendinger, P. (2001). The new right and neighbourhood regeneration. Housing studies 16 (3), 311-334.

Urban Audit, 2001; dostopno na www.urbanaudit.org (2. 10. 2007) 